\title{
Building Capable Organization: A Study On Strategic Responses To Increased Global Competition
}

Jifu Wang, (Email: wangj@uhv.edu), University of Houston, Victoria Luh-Yu Ren, (Email: renl@uhv.edu), University of Houston, Victoria

\begin{abstract}
While the government still plays a critical role in capitalizing organizational market transformation, firms work hard to improve their management capabilities to manage this transformation. This article outlines the strategic challenges facing a China's electric leader as the level of both global and domestic competition rises, and identifies the range of strategic responses being made to overcome these challenges. As the firm builds competitive capabilities, its "battle tested" strategies may provide useful lessons for today's managers who are also facing a growing range of competitive challenges in the global marketplace.
\end{abstract}

\section{INTRODUCTION}

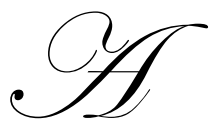

s the primary economic institutions in China, state-owned enterprises (SOEs) carry the primary burden for most of China's social welfare system, including housing, education, medical services, and retirement incomes. Today, SOEs are challenged to compete with foreign firms while still running China's welfare system, and struggling with central planning's legacies of operational redundancies, bureaucratic stagnation, and technological obsolescence (Morrison, 1999). These challenges are significant. After deregulation of the air cargo business, thirteen of the world's fifteen strongest airfreight companies establishing routes into Mainland China in 2001. In just eight months, the four major express delivery companies (FedEx, UPS, DHL and TNT) reduced China's airlines' revenue from air cargo services by 20 percent on air routes to the United States (ChinaOnLine, 2001). With some technical help from China's National High Technology Research and Development Program (863 Program), some SOEs are making significant progress, developing integrated management approaches which may set new performance benchmarks for Western managers.

This paper results from in-depth analysis of a Chinese SOE which adopted advanced management system to transform into competitive enterprise. Interviews were conducted with CEO, its key planning and engineering staff, and the top functional managers to provide data. They were asked to identify and rank their key challenges, specify their strategic responses, and describe the actual strategies, structures, and processes that have resulted in improved performance.

The government 863 Program, launched in March 1986, was intended to enhance China's international competitiveness and improve China's overall R\&D capability in high technologies (www.863.org.cn). The program covers 20 subject areas selected from eight priority areas: Biotechnology, Information, Automation, Energy, Advanced Materials, Marine, Space and Laser. All except space and laser areas are managed by China's Ministry of Science and Technology (MOST). By 2001, the 863 Program had supported more than 10,000 projects. The year 2000 was the year targeted for full implementation of the programs' results. The SOEs participating in this study were selected from participants in China's National High Tech Program for Automation Technology, which supports the development and implementation of best practices in computer-based management systems. 
- The CIMSNET project, jointly undertaken by 10 universities and 5 institutes in China, is complete. The network comprises a central station and 15 sub-stations, and has platforms for CIMS research, promotion and application, information dissemination and management.

- $\quad$ The CIMS Center of Hua Zhong University of S\&T was granted a University Lead Award by the Society of Manufacturing Engineers (SME). Tsinghua University received its second award since 1994. China is the second country to receive the award more than once, after the USA.

- $\quad$ After the research and development of CIMS industrialization was completed, six major industrialization projects were implemented, including a new type of numerical control system (NC), a rapid prototype manufacturing system (RPM), a three dimensional geometric modeling system (3DCAD), a product data management system (PDMS), an enterprise resource planning system (ERP) and a database management system (DBMS). Ten series of CIMS target products were designed initially, covering over $85 \%$ of the software and hardware products needed for the informatization of enterprises.

- $\quad$ Ten CIMS training centers were established nationwide and nearly 400,000 personnel received CIMS training, including 37,000 chief engineers and experts from companies. A distance CIMS training program was also launched.

Harbin Electric, China's largest producer of power generation equipment, one of the firms that the Chinese government selected in applying CIMS to enhance firm management evaluation and control process. It has seen foreign firms garner more than $40 \%$ share of the power generation equipment market since the government opened the market in 1995 .

\section{HARBIN ELECTRIC MACHINERY COMPANY LTD.}

Harbin Electric Machinery Company Ltd. (HEC), former Harbin Electric Machinery Works, was found in 1951, and was one of the 156 industrial bases that were built with the aide of Russia. HEC is the leading manufacturer of thermal and hydropower equipment and complete power stations in China. HEC has 9830 employees, including technical staff of 1840. HEC has produced an accumulated total capacity of electric power generating equipment of $49000 \mathrm{MW}$, about one third of total installed capacity of China-made units. HEC has also exported power-generating equipment to Asia, Africa, America, and Europe, and as established substantial economic and technical cooperation relations with 28 overseas firms in 12 countries.

\section{Industry Competitive Situation Analysis}

China's electric power industry also experienced an oversupply problem, due in part to slower Chinese economic growth owing to the Asian economic crisis. While residential demand was up 10.5 percent in 1998 over 1997, demand from heavy industry, the main consumer of electric power in China, was unchanged.

The Chinese government responded to the short-term oversupply in part by implementing a drive to close down small thermal power plants and imposing a moratorium on approval of new power plant construction. Most of the small plants are diesel or coal-fired plants, which were opened by provincial or municipal governments as demand grew in the 1980's, and are relatively inefficient and environmentally damaging.

\section{Domestic Competition}

There are approximately 600 domestic boiler factories, which produce residential and industrial boilers, among them Harbin Boiler Factory, Shanghai Boiler Factory and Dongfang Boiler Factory are the biggest, occupying nearly 60 percent of the market. There are a few large, electric machine factories in Shanghai (Shanghai Electric Machinery Factory), Sichuan (Chengdu Electric Machinery Factory), and Harbin (Harbin Electric Machinery Factory), which all cooperate with foreign companies in the technology field.

Some institutes and universities also contribute to the development of clean coal technology such as Shanghai Institute of Industrial Boilers and the Second Design Institute of Hangzhou (both of which belong to the 
State Machine-Building Industry Bureau), Qinghua University, Harbin Institute of Technology, Xi'an Traffic University, and Zhejiang University.

\section{US Market Share}

During the Summit between Presidents Bill Clinton and Jiang Zemin in October 1997, the United States announced an initiative of cooperation in energy and environmental science, technology and trade between the two nations. A joint program of conducting research and expanding efficiency and clean energy technologies was planned. Such expanding cooperation between China and the United States will open new investment and trade opportunities for U.S. companies, as U.S. technologies can help China meet the challenges of its energy and environmental needs. U.S. companies can concentrate on providing four main areas of technology to the Chinese market, those for improving coal quality, increasing coal-combustion efficiency, improving post-combustion particulates and improving coal use in urban households.

\section{Global Competition}

Globally, the electric equipment market is matured for the developed countries. Many giant electric equipment and facility manufacturers in the developed countries suffer from drastic decrease in production owing to a steady drop of market demand. Merges, restructuring and acquisition became a common practice in this industry all over the world. Zheng, the Vice President, explained that well known companies such as GE, and Westinghouse Electric Company, were doing well in 1970s and 1980s, when they generated more than 20 million kilowatts every year. But things started to go from bad to worse from late 1980s. When Zheng visited GE in early 1999, he saw in the factory of 0.1 million square meters had only one 0.35 million kilowatt generator for Qilihe in China.

Like General Electric (GE), most of the famous electric equipment suppliers focused their attention on the China market, where there was steady increase of demand because of the fast development since 1978. The coming in of these companies equipped with advanced technology and rich production experiences has made the life harder for the Chinese domestic electric manufacturers. Since 1995, more than 40 percent of Chinese market has been taken by the foreign suppliers.

\section{STRATEGIC RESPONSES}

\section{Strategy for Technological Innovation}

HEC established an R\&D center, the high-caliber Harbin Research Institute of Large Electric Machinery, which is the base for significant scientific research and product development for HEC. It is also the advisory body and leading institute for all the large electric machinery and hydro turbines in the country. The institute has 40 test stations equipped with advance testing and measuring facilities, and a workshop. It has seven research sections, including electric machine testing, hydro testing, ventilation testing, etc., and a workshop for machining tested components. The institute is equipped with an internationally advanced high head hydraulic test stand, and a 3000-ton thrust bearing test stand. Both are world class. It mainly conducts testing, research, and development of large hydroelectric power generating units, large turbo-generators, large AC \& DC motors and control equipment related to electric machinery products.

HEC has attempted technological innovation, and developed some high-tech products to differentiate from other competitors. The long-term objective is to keep the competitive edge by sustaining some products or technology that are hard for other firms to imitate and expensive to copy.

\section{Quality Strategy}

In the process of reform and development, HEC has improved its technical and product quality level significantly. HEC has formed an excellent quality "assurance system and obtained the certificate for qualified quality 
system of " GB/T19001. HEC has adopted overall quality control and work site management systems. All the main products are produced to international standards. The company has been ISO 9001 certified since 1994.

A project management technique, with quality control as its core, control project quality and meets the requirements of customers and contract specifications. According to ISO9001 certification initiated in 1994, HEC had a good quality system, including a quality assurance standard of design, development, manufacture, installation and service. Certification (No. 96003) was issued by VTI of China on April 25, 1996, and issued by FMRC (96081. IV) of U.S.A on August 5, 1996.

HEC issues a Quality Plan for specific projects, in which specific quality precautions, source and sequence of activities are stipulated, and the objective of quality control over the project is defined. With quality control management, HEC can provide its customers with confidence and objective evidence that it can supply you reliable premium quality power equipment and facilities.

\section{Product Strategy}

HEC has established the marketing strategy that is profit centered, led by product development, ensured by excellent quality, bases on scientific administration, and driven by the market. HEC introduced and optimized 60 MW turbo generators, 210 MW turbo generators for Pakistan and 2050 rolling mill motors manufactured to internationally advanced standards on both product quality and technological attributes. HEC won the State's scientific and technical progress super grade prize and gold medal prize for Gezhouba 125 MW hydro units and silver medal prize for Yunfeng 100MW, Taipingwan 47.5 MW hydro units. HEC was awarded National Grade I Enterprise, "May 1st" Labor Prize Certificate, Quality Control Prize of MMI, National Excellent Enterprise (Gold Horse Prize).

HEC has built a modernized turbo-generator workshop with a $36 \mathrm{M}$ span, a crane of 400 tons, and a worldclass stator frame machining center and shaft machining center. HEC has solved the machining and transportation problems of large pieces for Yantan power plant on the Coast of Bohai Sea that will help the Three Gorges project.

After several technical improvements between China's Seventh and Eighth Five-Year Economic Plans, HEC reached an annual output of 3,500 MW for turbo generators, 800-1,200 MW for hydro power generating units and 600 MW for AC and DC motors. HEC now can produce $300 \mathrm{MW}$ and $600 \mathrm{MW}$ turbo generators in batches.

By the end of 1997, HEC had produced altogether 57,466 MW for power generating equipment and 11,733 MW for DC and AC motors. The hydropower generating units produced by HEC accounted for more than half the total installed capacity produced domestically in China and HEC installed 120 hydro power stations in 22 provinces. The turbo generators made by HEC accounted for one third of the total installed capacity and HEC installed 132 thermal power plants in 22 provinces.

HEC has exported products to Canada, Congo, Korea, Pakistan, the Philippines, Turkey, U. S. A., Venezuela and some other countries. The contract value of the exported products is up to 345 million USD.

\section{Strategy for Business Alliance}

Recent years, HEC has built up close cooperation relationships with about 30 companies in 12 countries. It has established good strategic partnerships with Hitachi, Siemens, Voith, C. G. E. LME, and periodically exchanges technologies between each other. HEC and Bohai Bay Shipbuilding Works have formed a joint venture, the Northeast Binhai Hydroelectric Large Machinery Plant, where it installed large scale manufacturing equipment such as the $16 \mathrm{M}$ vertical lathe, $\varnothing 250$ milling machine, $\varnothing 12.6 \mathrm{~m}$ furnace, and welding positioners. Large hydroelectric equipment can be made in this plant and delivered directly by sea. 


\section{CONCLUSION}

While HEC was the most successful of our sample, the remaining SOEs had also made similar strides. Having transformed its "branch plant" operations to vibrant competitive organizations that are beginning to enter the global marketplace, these SOEs have transformed their business activities. To improve their capital structures, they adopted modern corporate structures, convinced government ministries and banks to convert excessive debt into stock holdings and take board positions. Several firms issued stock in Hong Kong and the USA capital markets. Others have developed joint venture partners to provide additional capital, as well as needed know-how and market access. Several have improved financial structures by either spinning out operations into new joint ventures, merging with similar domestic operations, or selling assets for cash. To improve the basic cost structure, local and national governments are taking responsibility for healthcare and unemployment, thereby reducing some of the SOE welfare burdens.

As seen in the HEC case, with asset rationalization comes the need for organizational transformations. All of the corporations in this study concentrated their initial efforts on improving management capabilities. But without strong organizations and management, these SOEs would not be effective in making such investments pay off. Recruiting, retraining, and keeping top employees have been a major struggle and have required significant changes in compensation and incentive schemes, including stock ownership. Without strong management teams, successful competitive strategies would not be likely found.

Besides improving management systems, the majority of these SOE have invested in upgrading operating facilities, product technologies, technical capabilities, and sales organizations to meet competitive requirements. This sample was split between purchasing new equipment and product designs or acquiring them through partnerships and joint ventures. While the industries covered by this sample were highly varied, most have refocused their productmarket strategies, implemented advanced cost management systems, and utilized information processing capabilities for tracking organizational and managerial performance. Most have acquired ISO9000 certifications and utilized the government's 863 projects to access advanced management and technical know-how.

Capable organizations consist of core competencies that are a combination of resources (e.g. materials, plants, knowledge, trademarks, skills, etc.) that are difficult for competitors to imitate and that create sustained competitive advantage. Core competencies enable the company to execute critical processes that create customer value at best-in-class standards. It demonstrates what the firm is good at, what customers' value, and what competition would have difficulty imitating. Core competencies are represented by the firm's people, technology, processes and culture. Dell's direct sell model is its core competency. To be core competencies, it should be strategically important to the business, relevant to the markets the firm serves, superior to competitors, and create sustainable value for customers.

Through its core competencies, a firm can determine where to transfer competencies within its organization and identify opportunities for profitable diversification. By linking the competitive environment with its core competencies, the company would be able capitalize on new business opportunities for profitable growth. PepsiCo was able to transfer its core competencies with the acquisition of Gatorade from Quaker Oats and Tropicana from Seagram in order to compete head-to-head with Coca-Cola's PowerAde and Minute Maid brand.

Another way to establish and sustain a capable organization, as indicated in HEC case, is to continue to create links across businesses and functional units, encourage communication and involvement, and place strong value on communicating across organizational boundaries. The purpose here is to reinforce the interacting competencies and create more synergies.

With China's rapid transformation into a market-driven economy, SOE managers have faced the challenges of their lives. Under central planning system, competition for markets, products, or prices was forbidden and people, capital, and natural resources were allocated according to the central plan. Managerial competences, technological innovations, and broad product offerings were discouraged, and economic incentives were non-existent. In little more 
than two decades, these characteristics have been reversed, and managers must change everything about their companies if they expect to survive.

As SOE managers successfully adapt their strategies to the new competitive business environment, Western executives should take notice of the continued improvements in performance and market positions of Chinese firms. Like HEC, the SOEs in this sample are successfully adopting advanced management techniques and developing strategies that are putting them into the ranks of world leaders. While not all SOEs have been as successful in overcoming decades of central planning, bureaucratic government leadership, and poor internal information systems and controls, nearly every industry now has an example of a successful transformation. Challenges to build competitive product lines and to compete in local and international markets demand world-class management techniques. HEC illustrates well how SOEs have faced these challenges and become major competitors in a relatively short time period. It seems appropriate for Western managers to take notice and make sure they are benchmarking the right firms. SOEs may provide an interesting model for future management techniques.

The authors give special thanks to Professor Cheng Wu of Tsinghua University for his help in selecting the SOEs and gaining access for research.

\section{REFERENCES}

1. Anonymous. (20 September, 2001). China airfreight buffeted by foreign carriers. ChinaOnLine.

2. Online at http://www.863.org.cn/english/about_863/index.html.

3. Morrison, W.M. (1999). China's Economic Conditions. Foreign Affairs, Defense, and Trade Division. National Council for Science and the Environment.

\section{NOTES}

